\title{
Comparison of $16 S$ rDNA-based PCR and checkerboard DNA-DNA hybridisation for detection of selected endodontic pathogens
}

\author{
JOSÉ F. SIQUEIRA, ISABELA N. RÔÇAS, MILTON DE UZEDA, ANA P. COLOMBO \\ and KÁTIA R. N. SANTOS \\ Institute of Microbiology 'Prof. Paulo de Góes', Federal University of Rio de Janeiro, Rio de Janeiro, RJ, Brazil
}

\begin{abstract}
Molecular methods have been used recently to investigate the bacteria encountered in human endodontic infections. The aim of the present study was to compare the ability of a 16S rDNA-based PCR assay and checkerboard DNA-DNA hybridisation in detecting Actinobacillus actinomycetemcomitans, Bacteroides forsythus, Peptostreptococcus micros, Porphyromonas endodontalis, Por. gingivalis and Treponema denticola directly from clinical samples. Specimens were obtained from 50 cases of endodontic infections and the presence of the target species was investigated by whole genomic DNA probes and checkerboard DNA-DNA hybridisation or taxon-specific oligonucleotides with PCR assay. Prevalence of the target species was based on data obtained by each method. The sensitivity and specificity of each molecular method was compared with the data generated by the other method as the reference - a value of 1.0 representing total agreement with the chosen standard. The methods were also compared with regard to the prevalence values for each target species. Regardless of the detection method used, T. denticola, Por. gingivalis, Por. endodontalis and $B$. forsythus were the most prevalent species. If the checkerboard data for these four species were used as the reference, PCR detection sensitivities ranged from 0.53 to 1.0 , and specificities from 0.5 to 0.88 , depending on the target bacterial species. When PCR data for the same species were used as the reference, the detection sensitivities for the checkerboard method ranged from 0.17 to 0.73 , and specificities from 0.75 to 1.0 . Accuracy values ranged from 0.6 to 0.74. On the whole, matching results between the two molecular methods ranged from $60 \%$ to $97.5 \%$, depending on the target species. The major discrepancies between the methods comprised a number of PCR-positive but checkerboard-negative results. Significantly higher prevalence figures for Por. endodontalis and $T$. denticola were observed after PCR assessment. There was no further significant difference between the methods with regard to detection of the other target species.
\end{abstract}

\section{Introduction}

Dental periapical diseases are caused primarily by the spread of micro-organisms from the root canal of the tooth. Root canal infections have a mixed microbiota usually composed of three-to-seven bacterial species and dominated by anaerobic bacteria [1-3]. Studies utilising culture methods have revealed that the putative endodontic pathogens include Porphyromonas spp.,

Received 22 Feb. 2002; revised version received 10 May 2002; accepted 22 May 2002.

Corresponding author: Dr J. F. Siqueira (e-mail: siqueira@ estacio.br).
Prevotella spp., Fusobacterium nucleatum, species of the Streptococcus anginosus group, Peptostreptococcus spp., Eubacterium spp. and Actinomyces spp. [1,3].

Molecular genetic methods, particularly PCR methodology, are more specific, sensitive and rapid than culture and can detect unculturable or fastidious microorganisms. Furthermore, molecular methods allow a more precise identification of cultivable bacterial strains with a phenotypically divergent behaviour and are not dependent on cell viability. The latter factor is particularly advantageous in the study of strictly anaerobic infections, where cell death can occur during sampling and transportation. For these reasons, molecular technology has been used widely to survey 
clinical specimens directly for the occurrence of pathogenic micro-organisms $[4,5]$.

Recently, a method was introduced for hybridising large numbers of DNA samples against large numbers of DNA probes on a single support membrane, i.e., checkerboard DNA-DNA hybridisation [6]. It permits the simultaneous determination of the presence of a multitude of bacterial species in single or multiple clinical samples and is particularly applicable in epidemiological research. Studies with this molecular method have provided substantial new information for a better understanding of the microbiology of periodontal diseases $[7,8]$.

In recent years, molecular methods have also been used to investigate the microbiota associated with infected root canals and with acute periapical abscesses [2, 920]. These methods have provided significant additional knowledge regarding the composition of the endodontic microbiota. For instance, molecular technologies have allowed for the first time the detection of B. forsythus [2, 9, 15], T. denticola [15, 16], T. maltophilum [12], and Pr. tannerae [20] in infected root canals in relatively high prevalences. Furthermore, other fastidious bacterial species, such as Por. endodontalis [13, 18], Slackia exigua [11], Mogibacterium timidum [11] and Eubacterium saphenum [11], have been reported in endodontic infections in higher prevalence values when molecular methods were used.

The ability of a new procedure to detect target microorganisms in clinical samples has been compared with that of culture, which has been long considered as the primary standard reference method. When such comparisons involved molecular methods, they have usually revealed high sensitivities relative to culture [21-23]. Such results are generally due to the lower detection limit of molecular methods when compared with culture, resulting in a larger number of positive cases. This is particularly important when monitoring the prevalence of uncultivable or particularly fastidious strict anaerobes in oral samples. As a consequence, culture has been questioned recently with regard to function as a primary reference method [22-25].

As molecular methods are being employed increasingly to investigate clinical specimens for the presence of micro-organisms, this study compared the ability of two molecular methods - a 16S rDNA-based PCR assay and checkerboard DNA-DNA hybridisation - to detect specific putative endodontic pathogens.

\section{Materials and methods}

\section{Specimen sampling}

Specimens were obtained from patients referred for root canal treatment to the Department of Endodontics, Estácio de Sá University, Rio de Janeiro. Cases of acute periapical abscess were selected from adult patients who had been referred for emergency treatment to three hospitals in Rio de Janeiro. Only teeth with dental caries and a necrotic pulp were included. A total of 50 samples of endodontic infection was obtained consisting of 25 samples from cases of chronic periapical disease and 25 from cases of acute periapical abscess. Selected teeth did not have a periodontal pocket $>4 \mathrm{~mm}$.

Each tooth with chronic disease was cleaned with pumice, isolated with a rubber dam and the surrounding field was cleansed with $\mathrm{H}_{2} \mathrm{O}_{2} 3 \%$ followed by sodium hypochlorite $2.5 \%$ solution. An access cavity was made with a sterile bur without water spray. The operative field, including the pulp chamber, was then swabbed with sodium hypochlorite $2.5 \%$. This solution was inactivated with sterile sodium thiosulphate $5 \%$. If the root canal was dry, a small amount of sterile saline solution was introduced into the canal. Samples were initially collected by means of a size 15 K-type file (Dentsply/Maillefer, Ballaigues, Switzerland) with the handle removed. The file was introduced to a level $c$. $1 \mathrm{~mm}$ short of the tooth apex, based on diagnostic radiographs, and a discrete filing motion was applied. Two sequential paper points were then placed to the same level and used to soak up the fluid in the canal. Each paper point was retained in position for $1 \mathrm{~min}$. The cut file and the two paper points were then transferred to cryotubes containing 1-ml of dimethyl sulphoxide $5 \%$ in trypticase-soy broth (Difco) (TSBDMSO). Samples were immediately frozen at $-20^{\circ} \mathrm{C}$.

In the case of acute infection, the overlying oral mucosa was prepared with a solution of chlorhexidine gluconate $2 \%$. Pus was collected by aspiration with a sterile wide-bore needle and syringe. The pus was transferred to TSB-DMSO and frozen.

\section{DNA extraction and preparation of DNA probes}

Whole genomic DNA probes were prepared from the following bacterial strains: Actinobacillus actinomycetemcomitans (ATCC 43718), B. forsythus (ATCC 43037), P. micros (ATCC 33270), Por. endodontalis (ATCC 35406), Por. gingivalis (ATCC 33277) and $T$. denticola (B1 strain, Forsyth Dental Center).

Bacterial strains from lyophilised stocks were cultured anaerobically on blood agar plates for 3-7 days at $37^{\circ} \mathrm{C}$. The growth was harvested and placed in $1.5-\mathrm{ml}$ microcentrifuge tubes containing $1 \mathrm{ml}$ of TE buffer (10 mM Tris-HCl, $0.1 \mathrm{~mm}$ EDTA, pH 7.6). Cells were washed twice by centrifugation in TE buffer at $2500 \mathrm{~g}$ for $10 \mathrm{~min}$. The cells were resuspended and lysed with either SDS $10 \%$ and proteinase K (Sigma) $20 \mathrm{mg} / \mathrm{ml}$ for gram-negative strains or in $150 \mu \mathrm{l}$ of an enzyme mixture containing lysozyme (Sigma) $15 \mathrm{mg} / \mathrm{ml}$ and achromopeptidase (Sigma) $5 \mathrm{mg} / \mathrm{ml}$ in TE buffer, $\mathrm{pH}$ 8.0 , for gram-positive strains. The pelleted cells were 
resuspended by sonication for $15 \mathrm{~s}$ and incubated at $37^{\circ} \mathrm{C}$ for $1 \mathrm{~h}$. DNA was isolated and purified by the method described by Smith et al. [26]. The concentration of the purified DNA was determined by spectrophotometric measurement of the absorbance at $260 \mathrm{~nm}$. The purity of the preparations was assessed by the ratio of DNA to protein as measured by the ratio of the absorbance at $260 \mathrm{~nm}$ and $280 \mathrm{~nm}$. Whole genomic DNA probes were prepared from each of the test species by labelling $1 \mu \mathrm{g}$ of DNA with digoxigenin (Boehringer Mannheim, Indianapolis, IN, USA) by a random primer technique [27].

Clinical samples in TSB-DMSO were thawed at $37^{\circ} \mathrm{C}$ for $10 \mathrm{~min}$ and vortex mixed for $30 \mathrm{~s}$. Microbial suspension was washed three times with $100 \mu$ of double-distilled water by centrifugation for $2 \mathrm{~min}$ at $2500 \mathrm{~g}$. Pellets were then resuspended in $500 \mu \mathrm{l}$ of double-distilled water, boiled for $10 \mathrm{~min}$ and chilled on ice. After centrifugation to remove cell debris for $10 \mathrm{~s}$ at $9000 \mathrm{~g}$ at $4^{\circ} \mathrm{C}$, the supernate was collected for testing.

\section{Checkerboard assessment}

The checkerboard DNA-DNA hybridisation technique employed was a modification [20] of that described by Socransky et al. [6]. Briefly, denatured DNA from the clinical samples was fixed in individual lanes on a nylon membrane with a Minislot (Immunetics, Cambridge, MA, USA). A Miniblotter 45 apparatus was used to hybridise the digoxigenin-labelled whole chromosomal DNA probes at $90^{\circ} \mathrm{C}$ to the lanes of the clinical samples. After overnight hybridisation at $42^{\circ} \mathrm{C}$, membranes were washed at low and high stringency and bound probes were then detected with phosphataseconjugated antibody to digoxigenin and chemiluminescence. The sensitivity of this assay was adjusted to permit detection of $10^{4}$ cells of each target species by adjusting the concentration of each DNA probe. This procedure was used to provide the same sensitivity of detection for each species.

\section{PCR assessment}

Species-specific oligonucleotide primers were used to detect the target microbial species. A pair of ubiquitous bacterial primers that match almost all bacterial $16 \mathrm{~S}$ rRNA genes at the same position but not $18 \mathrm{~S}$ rRNA genes from eukaryotic cells was used as a positive control for the PCR reaction. It served to indicate the presence of bacteria in clinical samples. Table 1 lists the primers and the predicted amplicon lengths for the target bacterial species [14,21,28]. Primers were purchased from Oligos Etc. (Wilsonville, OR, USA).

Portions $(5 \mu \mathrm{l})$ of the supernate from clinical sample or $1 \mu \mathrm{l}$ of the reference strain nucleic acid (200 ng/ $\mu \mathrm{l})$ were amplified. The PCR reaction mixture used to assess the occurrence of all target species, except $P$. micros, was performed in $50 \mu \mathrm{l}$ of reaction mixture containing $1 \mu \mathrm{l}$ of each primer (40 pmol), $5 \mu \mathrm{l}$ of $10 \times$ PCR buffer (Gibco BRL, Gaithersburg, MD, USA), Taq DNA polymerase (Gibco BRL) 1.25 unit and $0.2 \mathrm{mM}$ of each deoxyribonucleoside triphosphate (dATP, dCTP, dGTP and dTTP) (Gibco BRL). Earlier experiments found the optimal $\mathrm{MgCl}_{2}$ concentration in the mixture to be $2.0 \mathrm{mM}$. PCR amplification with specific primers for $P$. micros was performed in a reaction volume of $100 \mu \mathrm{l}$, consisting of $5 \mu \mathrm{l}$ of clinical sample and $95 \mu \mathrm{l}$ of reaction mixture containing $10 \times$ PCR buffer, 2 units of Taq DNA polymerase, $1.5 \mathrm{mM} \mathrm{MgCl}_{2}, 0.2 \mathrm{mM}$ of each deoxyribonucleoside triphosphate and $50 \mathrm{pmol}$ of each primer.

The temperature profile for B. forsythus, T. denticola and ubiquitous primer included initial denaturation at $95^{\circ} \mathrm{C}$ for $2 \mathrm{~min}$, followed by 36 cycles of denaturation at $95^{\circ} \mathrm{C}$ for $30 \mathrm{~s}$, primer annealing at $60^{\circ} \mathrm{C}$ for $1 \mathrm{~min}$, extension at $72^{\circ} \mathrm{C}$ for $1 \mathrm{~min}$ and a final extension at $72^{\circ} \mathrm{C}$ for $2 \mathrm{~min}$ after the last cycle. The temperature profile for Por. endodontalis and Por. gingivalis included initial denaturation at $95^{\circ} \mathrm{C}$ for $2 \mathrm{~min}$, followed by 36 cycles of denaturation at $94^{\circ} \mathrm{C}$ for $30 \mathrm{~s}$, primer annealing at $60^{\circ} \mathrm{C}$ for $1 \mathrm{~min}$, extension at $72^{\circ} \mathrm{C}$ for $2 \mathrm{~min}$ and a final $72^{\circ} \mathrm{C}$ for $10 \mathrm{~min}$. For $A$.

Table 1. PCR primer pairs used for detection of putative endodontic pathogens

\begin{tabular}{|c|c|c|c|}
\hline Bacterial species & Primer pairs $\left(5^{\prime}-3^{\prime}\right)$ & $\begin{array}{l}\text { Amplicon } \\
\text { length } \\
\text { (bp) }\end{array}$ & $\begin{array}{c}\text { Reference } \\
\text { no. }\end{array}$ \\
\hline A. actinomycetemcomitans & $\begin{array}{l}\text { AAA CCC ATC TCT GAG TTC TTC TTC } \\
\text { ATG CCA ACT TGA CGT TAA AT }\end{array}$ & 557 & 21 \\
\hline B. forsythus & $\begin{array}{l}\text { GCG TAT GTA ACC TGC CCG CA } \\
\text { TGC TTC AGT GTC AGT TAT ACC T }\end{array}$ & 641 & 21 \\
\hline Por. endodontalis & $\begin{array}{l}\text { GCT GCA GCT CAA CTG TAG TC } \\
\text { CCG CTT CAT GTC ACC ATG TC }\end{array}$ & 672 & 28 \\
\hline Por. gingivalis & $\begin{array}{l}\text { AGG CAG CTT GCC ATA CTG CG } \\
\text { ACT GTT AGC AAC TAC CGA TGT }\end{array}$ & 404 & 21 \\
\hline P. micros & $\begin{array}{l}\text { TCG AAC GTG ATT TTT GTG GA } \\
\text { TCC AGA GTT CCC ACC TCT }\end{array}$ & 1074 & 14 \\
\hline T. denticola & $\begin{array}{l}\text { TAA TAC CGA ATG TGC TCA TTT ACA T } \\
\text { TCA AAG AAG CAT TCC CTC TTC TTC TTA }\end{array}$ & 316 & 21 \\
\hline Ubiquitous primer & $\begin{array}{l}\text { GAT TAG ATA CCC TGG TAG TCC AC } \\
\text { CCC GGG AAC GTA TTC ACC G }\end{array}$ & 602 & 21 \\
\hline
\end{tabular}


actinomycetemcomitans, the temperature profile included initial denaturation at $94^{\circ} \mathrm{C}$ for $30 \mathrm{~s}$, followed by 36 cycles of denaturation at $95^{\circ} \mathrm{C}$ for $30 \mathrm{~s}$, primer annealing at $55^{\circ} \mathrm{C}$ for $1 \mathrm{~min}$, extension at $72^{\circ} \mathrm{C}$ for $2 \mathrm{~min}$ and a final $72^{\circ} \mathrm{C}$ for $10 \mathrm{~min}$. PCR cycling conditions for $P$. micros comprised initial denaturation of $94^{\circ} \mathrm{C}$ for $5 \mathrm{~min}$, followed by 35 cycles of denaturation at $94^{\circ} \mathrm{C}$ for $1 \mathrm{~min}$, primer annealing at $55^{\circ} \mathrm{C}$ for $1 \mathrm{~min}$, extension at $72^{\circ} \mathrm{C}$ for $1.5 \mathrm{~min}$ and final extension at $72^{\circ} \mathrm{C}$ for $10 \mathrm{~min}$. Amplicons were stored at $-20^{\circ} \mathrm{C}$.

PCR cycling was performed in a DNA thermocycler (PTC-100, MJ Research, Watertown, MA, USA). Amplicons were analysed by agarose $1.5 \%$ gel electrophoresis at $4 \mathrm{~V} / \mathrm{cm}$ in Tris-borate EDTA buffer. The gel was stained with ethidium bromide $0.5 \mu \mathrm{g} / \mathrm{ml}$ and visualised on an ultraviolet transilluminator. The size markers used were 100-bp and 1-kb DNA ladder digests (Gibco BRL).

\section{Data analysis}

Prevalence of the target species was recorded based on data obtained by each method. The sensitivity, specificity and accuracy of bacterial detection of each molecular method were calculated with the data generated by the other method as the reference. The sensitivity was estimated as the number of matching positive results divided by the number of positive results in the reference technique. The specificity was estimated as the number of matching negative results divided by the number of negative results in the reference technique. The accuracy was estimated as the number of true positives (sensitivity) plus true negatives (specificity) divided by the total number of samples. The comparison between the methods with regard to the ability to detect each target species was also performed by the $\chi^{2}$ test.

\section{Results}

All samples were found to contain bacteria as demonstrated by PCR with the ubiquitous bacterial primer pair. Only one band of the predicted size (602 bp) was present for each root canal sample (data not shown).

In general, PCR detected bacteria more frequently than the checkerboard method. Fig. 1 shows an example of results of the two methods. Regardless of the detection method used, T. denticola, Por. gingivalis, Por. endodontalis and $B$. forsythus were the most prevalent species (Table 2). T. denticola was detected by PCR in 23 samples and by checkerboard in 5 samples. Four samples were positive by both methods. Por. gingivalis was identified in 16 cases by PCR and in 11 cases by checkerboard, with 8 matching positive results. Por. endodontalis was detected in 11 cases by PCR and in 4 cases by checkerboard. All four cases positive by a

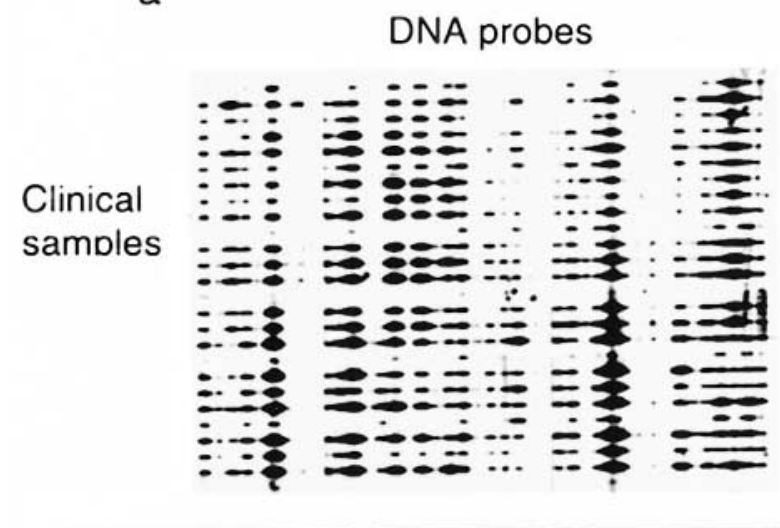

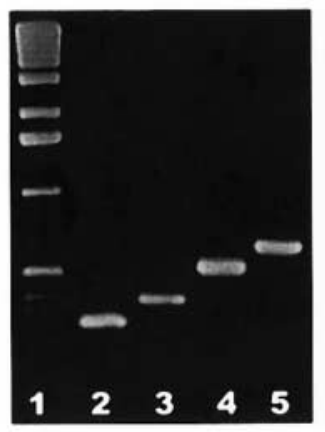

b

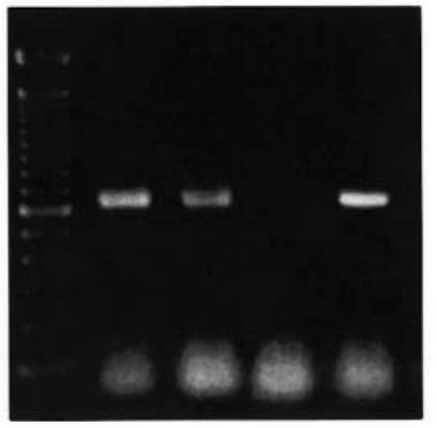

C
Fig. 1. Example of the two methods used. (a) Simultaneous detection of multiple bacterial species in clinical samples by the checkerboard DNA-DNA hydridisation method. The vertical lanes contain whole genomic probes of the target species and the horizontal lanes contain clinical samples. (b and c) Representative electrophoresis results of PCR. (b) Amplification of control reference DNA. Lane 1, 1-kb ladder; 2, $T$. denticola DNA; 3, Por. gingivalis DNA; 4, A. actinomycetemcomitans DNA; 5, Por. endodontalis DNA. (c) Positive and negative clinical samples for B. forsythus.

checkerboard were also positive by PCR. B. forsythus was more prevalent when examined by checkerboard (15 cases) than by PCR (11 cases). Matching positive results occurred in eight cases. P. micros was detected in five cases by PCR and in two cases by checkerboard. No matching positive results were found. A actinomycetemcomitans was detected only by checkerboard in one sample.

Matching results between the two molecular methods occurred in $60 \%$ of the samples for $T$. denticola, in $65 \%$ for $P$. micros, in $72 \%$ for Por. gingivalis, in $72 \%$ for Por. endodontalis, in $74 \%$ for B. forsythus and in $98 \%$ for $A$. actinomycetemcomitans. The highest number of matching positive results occurred for $B$. forsythus and Por. gingivalis (21\% of the samples).

The main discrepancy between PCR and the checkerboard method involved a number of PCR-positive but checkerboard-negative results, occurring in $28 \%$ of the samples for Por. endodontalis and $38 \%$ for T. denticola. Because of this, the PCR assay resulted in significantly higher prevalence figures for Por. endodontalis 
Table 2. Number of positive cases as detected by PCR and checkerboard assays

\begin{tabular}{|c|c|c|c|c|c|}
\hline \multirow[b]{2}{*}{ Bacterial species } & \multirow[b]{2}{*}{$\mathrm{n}^{*}$} & \multicolumn{3}{|c|}{ Number $(\%)$ of samples positive by } & \multirow[b]{2}{*}{$\begin{array}{c}\text { General } \\
\text { prevalence }^{\dagger}(\%)\end{array}$} \\
\hline & & PCR & Checkerboard & $\begin{array}{l}\text { Matching positive } \\
\text { results }(\%)\end{array}$ & \\
\hline A. actinomycetemcomitans & 40 & $0(0)$ & $1(3)$ & $0(0)$ & 3 \\
\hline B. forsythus & 39 & $11(28)$ & $15(39)$ & $8(21)$ & 46 \\
\hline Por endodontalis & 25 & $11(44)$ & $4(16)$ & $4(16)$ & 44 \\
\hline Por. gingivalis & 39 & $16(41)$ & $11(28)$ & $8(21)$ & 49 \\
\hline P. micros & 20 & $5(25)$ & $2(10)$ & $0(0)$ & 35 \\
\hline T. denticola & 50 & $23(46)$ & $5(10)$ & $4(8)$ & 48 \\
\hline
\end{tabular}

* Total number of cases tested.

${ }^{\dagger}$ General prevalence figures refer to the total number of samples positive for each bacterial species regardless of the method of detection.

$(\mathrm{p}<0.05)$ and T. denticola $(\mathrm{p}<0.01)$ when compared with checkerboard data. There was no further significant difference between the methods with regard to detection of the other target species $(\mathrm{p}>0.05)$.

If the checkerboard data for $T$. denticola, Por. endodontalis, Por. gingivalis and B. forsythus were used as the reference, PCR detection sensitivities ranged from 0.53 to 1.0 , and specificities from 0.5 to 0.88 , depending on the target bacterial species (Table 3 ). When PCR data for the same species were used as the reference, the detection sensitivities for the checkerboard method ranged from 0.17 to 0.73 , and specificities from 0.75 to 1.0 (Table 4). Accuracy ranged from 0.6 to 0.74 , depending on the target species. Data regarding sensitivity, specificity and accuracy were not calculated for A. actinomycetemcomitans detection because of the low prevalence of this organism. With regard to the detection of $P$. micros, both methods showed absence of sensitivity (no matching positive result) and specificity of 0.72 for PCR (checkerboard data as reference) and 0.87 for checkerboard (PCR data as reference). The accuracy value obtained for $P$. micros was 0.65 .

\section{Discussion}

According to the epidemiological definition, sensitivity is the concept of a test result being positive when it should be positive, i.e., it is positive when the primary reference test is also positive (true positive). In this sense, specificity is the concept that a test result is negative when it should be negative (true negative). A given method may show low sensitivity because of a lower detection rate of the target species when compared with the reference method, indicating an inferior performance by the test method; or it may show less cross-reactivity by the test method with nontarget species than by the reference method, indicating a superior performance by the test method. Similarly, the test method may have low specificity because of occurrence of cross-reactivity with non-target species by the test method, indicating an inferior performance of the test method; or it may have a higher detection rate of the target species by the test method than by the reference method, indicating a superior performance of the test method [29]. The sensitivity and the specificity of a useful diagnostic test should be reliably established by comparison with a reference test. In the absence of an indisputable reference method, the present study evaluated both the sensitivity and specificity of two molecular methods by utilising the data generated by each method as reference for the other with regard to the identification of selected bacterial species directly from clinical samples of endodontic infections.

As there were several PCR-positive/checkerboardnegative results, the checkerboard assay showed low sensitivity values for $T$. denticola (0.17), Por. endodontalis (0.36) and Por. gingivalis (0.5), when PCR data were used as reference. The possibility exists that false-positive results for PCR may have occurred because of cross-reactivity, as the $16 \mathrm{~S}$ rDNA-based PCR may have detected microbial species with close phylogenetic relationships to the target bacteria. Such closely related species might have $16 \mathrm{~S}$ rRNA genes that differ in only a few nucleotides and might not be

Table 3. Prevalence of selected endodontic pathogens as detected by checkerboard DNA-DNA hybridisation and sensitivity and specificity of the PCR assay with checkerboard data as reference

\begin{tabular}{lcccc}
\hline Bacterial species & Prevalence (\%) & Sensitivity & Specificity & Accuracy \\
\hline A. actinomycetemcomitans & 3 & $\mathrm{NC}$ & $\mathrm{NC}$ & $\mathrm{NC}$ \\
B. forsythus & 39 & 0.53 & 0.88 & 0.74 \\
Por. endodontalis & 16 & 1.0 & 0.67 & 0.72 \\
Por. gingivalis & 28 & 0.73 & 0.71 & 0.72 \\
P. micros & 10 & 0 & 0.72 & 0.65 \\
T. denticola & 10 & 0.8 & 0.5 & 0.6 \\
\hline
\end{tabular}

$\mathrm{NC}$, not calculated because of low prevalence. 
Table 4. Prevalence of selected endodontic pathogens as detected by the $16 \mathrm{~S}$ rDNA-based PCR assay and sensitivity and specificity of the checkerboard with PCR data as reference

\begin{tabular}{lcccc}
\hline Bacterial species & Prevalence (\%) & Sensitivity & Specificity & Accuracy \\
\hline A. actinomycetemcomitans & 0 & $\mathrm{NC}$ & $\mathrm{NC}$ & $\mathrm{NC}$ \\
B. forsythus & 28 & 0.73 & 0.75 & 0.74 \\
Por. endodontalis & 44 & 0.36 & 1.0 & 0.72 \\
Por. gingivalis & 41 & 0.5 & 0.87 & 0.72 \\
P. micros & 25 & 0 & 0.87 & 0.65 \\
T. denticola & 46 & 0.17 & 0.96 & 0.6 \\
\hline
\end{tabular}

$\mathrm{NC}$, not calculated because of low prevalence.

distinguishable by $16 \mathrm{~S}$ rRNA gene analysis. Nonetheless, the higher prevalence values obtained with PCR are more likely to be explained by the high detection rate of this method. The sensitivity of the checkerboard DNA-DNA hybridisation assay used in the present study was set to $10^{4}$ cells of a bacterial species by adjusting the concentration of each DNA probe in the hybridisation buffer. On the other hand, the detection rate of the PCR assay used in the present study was 25-100 cells of the target species. Furthermore, although the possibility of cross-reactivity should not be discarded, it may be considered minimal because no cross-reaction was observed for the primers used when tested against a large number of other oral micro-organisms [14-17,21,28]. The primers used amplified a band of the predicted size only for each target species and no amplification of different sized bands was observed under the PCR conditions used in the present study.

Cross-reactivity for the whole DNA probe may explain the PCR-negative/checkerboard-positive results [30]. Although whole genomic probes are more likely to cross-react with non-target bacteria due to the presence of homologous sequences between different bacterial species [29], the results of this study suggested that this was not a common occurrence. It can be attested by the fact that when PCR was used as reference, the checkerboard assay gave relatively low sensitivity figures for most target bacteria, except for B. forsythus. Socransky et al. [7] reported that $>92 \%$ of all test probes:heterologous species reactions did not exhibit cross-reactions under the conditions of the assay. Some probes, such as those targeting B. forsythus, Por. gingivalis and $T$. denticola, did not exhibit crossreactions with any heterologous species tested. When cross-reactions were observed they were always within genera and were quite limited. Although the occurrence of cross-reactivity should not be discarded as an explanation for the fact that some samples yielded the test species on checkerboard but not on PCR assessment, this discrepancy is most likely to have occurred because of the use of different volumes of sample material for the two methodologies (30 $\mu \mathrm{l}$ for checkerboard and $5 \mu \mathrm{l}$ for PCR assay). Therefore, because different volumes of samples may contain variable numbers of target bacteria, this factor may have contributed to the occurrence of PCR-negative/ checkerboard-positive results.

The results of the present study with two different molecular methods confirmed that B. forsythus and T. denticola, (two particularly fastidious periodontal pathogens that have not been cultured previously from endodontic infections), are components of the endodontic microbiota and may play a role in the pathogenesis of periapical disease. Moreover, the two cultivable species of the genus Porphyromonas that had been isolated previously from endodontic infections by culture were also detected by molecular methods but with higher prevalence values. In addition to being fastidious bacteria, it is likely that some strains within the species may be uncultivable or may show a phenotypically divergent behaviour and thus may be detected only by molecular methods. On the other hand, the results of the two molecular methods with regard to the detection of $P$. micros and A. actinomycetemcomitans were apparently similar to those from cultural procedures. Whereas $P$. micros has been isolated from $20-35 \%$ of cases of endodontic infection $[1,3]$, A. actinomycetemcomitans, which is recognised as an important periodontal pathogen, has been encountered only occasionally in root canal infection.

There was a reasonable degree of agreement between the two molecular methods tested in this study. In general, the PCR and the checkerboard detection assays were relatively compatible and demonstrated a reasonable number of matching results for most of the target species, particularly with regard to the matching negative results. However, the PCR method yielded the highest number of positive results for most target species, and prevalence figures of Por. endodontalis and $T$. denticola were significantly higher by PCR assessment than by checkerboard assay. Therefore, PCR was significantly more likely to detect these species in samples from endodontic infections than the checkerboard method. Most of the discrepancies between checkerboard and PCR assays may have been due to the lower detection limit of the latter method. It should be borne in mind that poor sensitivity/specificity values may be a reflection of the inadequacies of the standard methods. Therefore, because of the absence of an indisputable reference standard, no definitive conclu- 
sions may be drawn on the capability of a given method to better reflect reality.

This study was supported in part by grants from the Brazilian Governmental Institutions CNPq, FAPERJ and PRONEX.

\section{References}

1. Sundqvist G. Associations between microbial species in dental root canal infections. Oral Microbiol Immunol 1992; 7: 257 262.

2. Siqueira JF, Rôças IN, Souto R, Uzeda M, Colombo AP Checkerboard DNA-DNA hybridization analysis of endodontic infections. Oral Surg Oral Med Oral Pathol Oral Radiol Endod 2000; 89: 744-748.

3. Gomes BPFA, Lilley JD, Drucker DB. Clinical significance of dental root canal microflora. J Dent 1996; 24: 47-55.

4. Pitt TL, Saunders NA. Molecular bacteriology: a diagnostic tool for the millennium. J Clin Pathol 2000; 53: 71-75.

5. Whelen AC, Persing DH. The role of nucleic acid amplification and detection in the clinical microbiology laboratory. Annu Rev Microbiol 1996; 50: 349-373.

6. Socransky SS, Smith C, Martin L, Paster BJ, Dewhirst FE, Levin AE. "Checkerboard" DNA-DNA hybridization. Biotechniques 1994; 17: 788-792.

7. Socransky SS, Haffajee AD, Cugini MA, Smith C, Kent RL. Microbial complexes in subgingival plaque. J Clin Periodontol 1998; 25: 134-144.

8. Ximénez-Fyvie LA, Haffajee AD, Socransky SS. Microbial composition of supra- and subgingival plaque in subjects with adult periodontitis. J Clin Periodontol 2000; 27: 722-732.

9. Conrads G, Gharbia SE, Gulabivala K, Lampert F, Shah HN The use of a $16 \mathrm{~S}$ rDNA PCR for the detection of endodontopathogenic bacteria. J Endod 1997; 23: 433-438.

10. Gatti JJ, Dobeck JM, Smith C, White RR, Socransky SS, Skobe Z. Bacteria of asymptomatic periradicular endodontic lesions identified by DNA-DNA hybridization. Endod Dent Traumatol 2000; 16: 197-204.

11. Hashimura T, Sato M, Hoshino E. Detection of Slackia exigua, Mogibacterium timidum and Eubacterium saphenum from pulpal and periradicular samples using the Polymerase Chain Reaction (PCR) method. Int Endod $J$ 2001; 34: 463-470.

12. Jung I-Y, Choi B-K, Kum K-Y et al. Identification of oral spirochetes at the species level and their association with other bacteria in endodontic infections. Oral Surg Oral Med Oral Pathol Oral Radiol Endod 2001; 92: 329-334.

13. Machado de Oliveira JC, Siqueira JF, Alves GB, Hirata R, Andrade AFB. Detection of Porphyromonas endodontalis in infected root canals by $16 \mathrm{~S}$ rRNA gene-directed polymerase chain reaction. $J$ Endod 2000; 26: 729-732.

14. Riggio MP, Lennon A, Smith A. Detection of Peptostreptococcus micros DNA in clinical samples by PCR. $J$ Med Microbiol 2001; 50: 249-254.
15. Rôças IN, Siqueira JF, Santos KR, Coelho AM. "Red complex" (Bacteroides forsythus, Porphyromonas gingivalis, and Treponema denticola) in endodontic infections: a molecular approach. Oral Surg Oral Med Oral Pathol Oral Radiol Endod 2001; 91: 468-471.

16. Siqueira JF, Rôças IN, Favieri A, Santos KRN. Detection of Treponema denticola in endodontic infections by 16S rRNA gene-directed polymerase chain reaction. Oral Microbiol Immunol 2000; 15: 335-337.

17. Siqueira JF, Rôças IN, Oliveira JCM, Santos KRN. Detection of putative oral pathogens in acute periradicular abscesses by 16S rDNA-directed polymerase chain reaction. J Endod 2001; 27: $164-167$.

18. Siqueira JF, Rôças IN, Oliveira JCM, Santos KRN. Molecular detection of black-pigmented bacteria in infections of endodontic origin. J Endod 2001; 27: 563-566.

19. Sunde PT, Tronstad L, Eribe ER, Lind PO, Olsen I. Assessment of periradicular microbiota by DNA-DNA hybridization. Endod Dent Traumatol 2000; 16: 191-196.

20. Xia T, Baumgartner JC, David LL. Isolation and identification of Prevotella tannerae from endodontic infections. Oral Microbiol Immunol 2000; 15: 273-275.

21. Ashimoto A, Chen C, Bakker I, Slots J. Polymerase chain reaction detection of 8 putative periodontal pathogens in subgingival plaque of gingivitis and advanced periodontitis lesions. Oral Microbiol Immunol 1996; 11: 266-273.

22. Papapanou PN, Madianos PN, Dahlén G, Sandros J. "Checkerboard" versus culture: a comparison between two methods for identification of subgingival microbiota. Eur J Oral Sci 1997; 105: 389-396.

23. Smith GL, Socransky SS, Smith CM. Non-isotopic DNA probes for the identification of subgingival microorganisms. Oral Microbiol Immunol 1989; 4: 41-46.

24. Loesche WJ. DNA probe and enzyme analysis in periodontal diagnostics. J Periodontol 1992; 6312 Suppl: 1102-1109.

25. Loesche WJ, Lopatin DE, Stoll J, van Poperin N, Hujoel PP. Comparison of various detection methods for periodontopathic bacteria: can culture be considered the primary reference standard? J Clin Microbiol 1992; 30: 418-426.

26. Smith GLF, Socransky SS, Smith CM. Rapid method for the purification of DNA from subgingival microorganisms. Oral Microbiol Immunol 1989; 4: 47-51.

27. Feinberg AP, Vogelstein B. A technique for radiolabeling DNA restriction endonuclease fragments to high specific activity. Anal Biochem 1983; 132: 6-13.

28. Tran T, Flynn MJ, Chen C, Slots J. Porphyromonas endodontalis in subgingival plaque. Clin Infect Dis 1997; 25 Suppl 2: S222-S223.

29. Chen C, Slots J. Microbiological tests for Actinobacillus actinomycetemcomitans and Porphyromonas gingivalis. Periodontol 2000 1999; 20: 53-64.

30. Melvin WL, Assad DA, Miller GA, Gher ME, Simonson L, York AK. Comparison of DNA probe and ELISA microbial analysis methods and their association with adult periodontitis. J Periodontol 1994; 65: 576-582. 